\title{
Brief Note on Papilloedema, Optic Neuritis and Optic Atrophy
}

\section{Dr Partha Haradhan Chowdhury ${ }^{1 *}$ and Brinda Haren Shah ${ }^{2}$}

${ }^{1}$ Ph.D. in Optometry (Gujarat State Government University) and Professor and Principal, Shree Satchandi Jankalyan Samiti Eye Institute - Pauri, Uttarakhand, India

${ }^{2}$ M. OPTOM, Practitioner, Ahmedabad, Gujarat, India

*Corresponding Author: Dr Partha Haradhan Chowdhury, Ph.D. in Optometry (Gujarat State Government University) and Professor and Principal, Shree Satchandi Jankalyan Samiti Eye Institute - Pauri, Uttarakhand, India.
Received: March 23, 2021

Published: April 16, 2021

(C) All rights are reserved by Dr Partha Haradhan Chowdhury and Brinda Haren Shah.

\section{Abstract}

This paper describes about papilloedema, optic atrophy and optic neuritis.

Keywords: Papilloedema; Optic Atrophy; Optic Neuritis

\section{Introduction}

\section{Papilloedema}

Papilloedema is a condition where edema is present on the optic nerve head. It is a non-inflammatory, bilateral condition. Mostly, it is associated with increased intra cranial tension. In this case, patient usually complains of nausea, vomiting, headache, deteriorated visual acuity, RAPD. Sometimes visual field is hampered and amaurosis fugax (Sudden loss of vision and regain it) is observed.

By the ophthalmoscopy, optic nerve head appears from its own position. Unilateral papilloedema occurs mainly due to inflammation.

As a rule, it is found when optic atrophy develops then papilloedema will not develop.

For treatment of the papilloedema, at first identify the case and treat it. Another way is, surgical decompensation of the optic nerve.

\section{Optic atrophy}

Optic atrophy is a degeneration of the optic nerve fibres and here actually loss of myelin sheath occurs and characterized by pal-

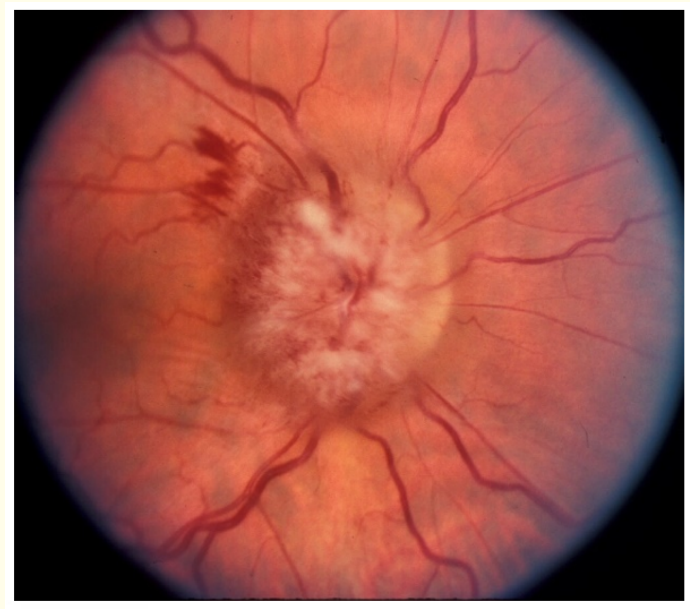

Figure 1 
lor of the optic nerve head. This pallor of the optic nerve head does not occur due to atrophy of the nerve fibre but it mainly occurs due to obliteration of nerve fibres on the optic nerve head capillaries.

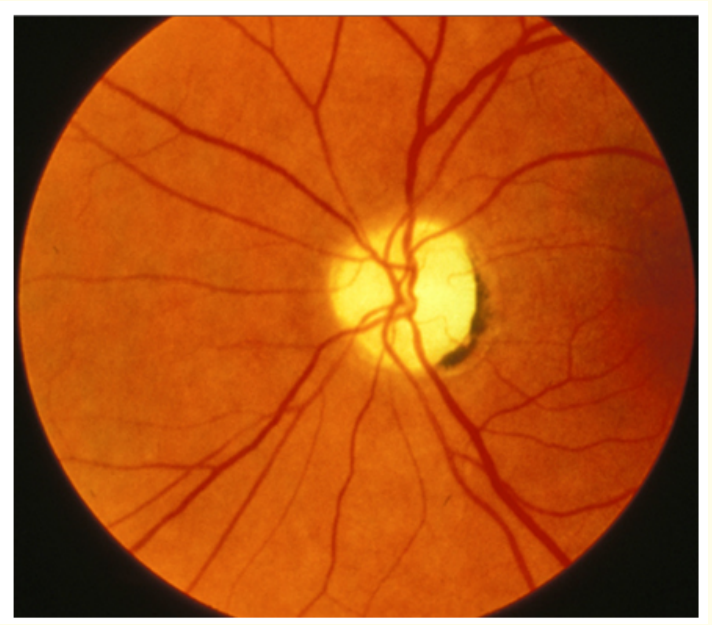

Figure 2

In case of optic atrophy, it is always remembered that there is deterioration of visual acuity which mainly occurs due to either ocular disease, systemic disease or trauma.

Treatment is according to the cause.

\section{Optic neuritis}

Inflammation of the optic nerve or demyelination of the optic nerve is called optic neuritis.

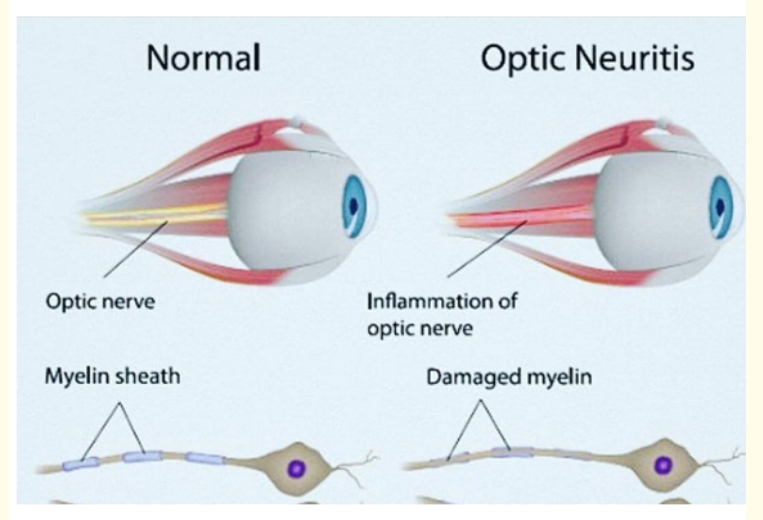

Figure 3
In this case, visual acuity of the patient is deteriorated.

Mild RAPD is present.

Feeling mild ocular pain when patient is asked to look up side and due to superior rectus muscle is involved.

Mild colour vision problem is found.

Always it is remembered that in case of optic neuritis, the inflammation is from the optic nerve head to lateral geniculate body.

\section{Causes:}

- Unknown reason (Idiopathic)

- De myelination

- Adjacent ocular structure inflammation

- Metabolic disorder like diabetes mellitus, pregnancy etc.

- To treat the optic neuritis, at first treat the cause [1-3].

\section{Bibliography}

1. Brad Bowling. "Kanski's Clinical Ophthalmology E-Book: A Systematic Approach". $8^{\text {th }}$ Edition (2016).

2. Sihota Radhika Tandon. "Parson's Diseases of the Eye". $22^{\text {nd }}$ Edition (2018).

3. Samar K Basak. “Clinical Ophthalmology” (2009).

\section{Assets from publication with us}

- Prompt Acknowledgement after receiving the article

- Thorough Double blinded peer review

- Rapid Publication

- Issue of Publication Certificate

- High visibility of your Published work

Website: www.actascientific.com/

Submit Article: www.actascientific.com/submission.php Email us: editor@actascientific.com

Contact us: +919182824667 